\title{
Editor's Report for Volume 128 (2014)
}

One hundred and thirty-five years is a long time for any endeavour, but an unbroken record of independently publishing a scientific journal for this length of time by a non-profit organization is a remarkable feat. As the oldest natural history society in Canada, the Ottawa Field-Naturalists' Club has much to be proud of in its publication of The Canadian Field-Naturalist since 1880.

Volume 128 of The Canadian Field-Naturalist exemplifies the important role of this journal as a forum for dispersing science on the distribution, taxonomy, biology, behaviour, ecology, and conservation of species across a broad range of taxa in North America. In volume 128, topics included distribution of species from under-surveyed regions in Canada, population decline of species-at-risk, landscape ecology, ethology, migration, impact of drought and anthropogenic activities, habitat use, morphological variation, and improved methods for field biology. The Canadian Field-Naturalist also continued to publish tributes on the lives of remarkable naturalists, which remains an important contribution to natural history.

Mailing dates for issues in volume 128 are as follows: 26 March 2014; 8 July 2014; 20 October 2014; 30 January 2015. A summary of the distribution of memberships in the Ottawa Field-Naturalists' Club and subscribers to The Canadian Field-Naturalist for 2014 is provided in Table 1. Note that institutional subscribers represent many thousands of users. The number of articles and notes in Volume 128 is summarized in Table 2 by topic. Totals for book reviews and new titles is given in Table 3, and the distribution of content by page totals per issue is provided in Table 4. Seventy-seven manuscripts were submitted to The Canadian Field-Naturalist in 2014. Of these, 62 were accepted for publication. A total of 28 Articles, 14 Notes, and 3 Tributes were published in 2014.

Trina Rytwinski, Assistant Editor, edited content, acted as an occasional Associate Editor, and acted as Editor-in-Chief for over three months. Trina's adept management of the journal was invaluable. Elizabeth
Morton and Sandra Garland proofed and edited manuscripts. We are grateful for the many years of excellent service that Elizabeth gave to the journal, and wish her well in her new endeavours. We also welcome Sandra Garland as the journal's new copy editor. Wendy Cotie typeset galleys, provided corrections for page proofs, and created pdfs; Roy John, Book Review Editor, requested books for review, selected reviewers, edited submitted reviews, and prepared the new titles listings; Jay Fitzsimmons, Journal Manager, managed financial accounts, issue mailing, and requests for back issues, conducted journal promotion through Twitter and other means, and provided digital content to subscribers. William Halliday prepared the Index with proofreading by Frank Pope. Sandra Garland, webmaster of the Ottawa Field-Naturalists' Club, posted tables of contents, abstracts, and pdfs on the CFN section of the OFNC website. Our Associate Editors managed manuscripts, provided reviews and recommendations, and guided authors through the revisions process. The Publication Committee, chaired by Dan Brunton and consisting of Paul Catling, Jay Fitzsimmons, Sandra Garland, Tony Gaston, Karen McLachlan Hamilton, Frank Pope, and Jeff Saarela, effectively guided the operation of the journal. I am indebted to our very dedicated team.

The following Associate Editors managed, assessed and reviewed manuscripts published in volume 128: R. Anderson, Canadian Museum of Nature, Ottawa ON (1); F. R. Cook, Emeritus Research Associate, Canadian Museum of Nature, Ottawa ON (5); J. Foote, Algoma University, Sault Ste. Marie ON (10); A. J. Gaston, Environment Canada (emeritus), Ottawa ON (5); S. Jung, Yukon Government, Whitehorse YT (3); D. F. McAlpine, New Brunswick Museum, St. John NB (2); D. W. Nagorsen, Mammalia Biological Consulting, Victoria BC (5); C. Renaud, Canadian Museum of Nature, Ottawa ON (3); T. Rytwinski, Carleton University, Ottawa ON (2); J. Saarela, Canadian Museum of Nature, Ottawa ON (3); J. Skevington, Agriculture and Agri-Food Canada (3).

TABLE 1. The 2014 circulation of The Canadian Field-Naturalist (2013 in parentheses). Compiled by Ken Young from the subscription list for 128(4).

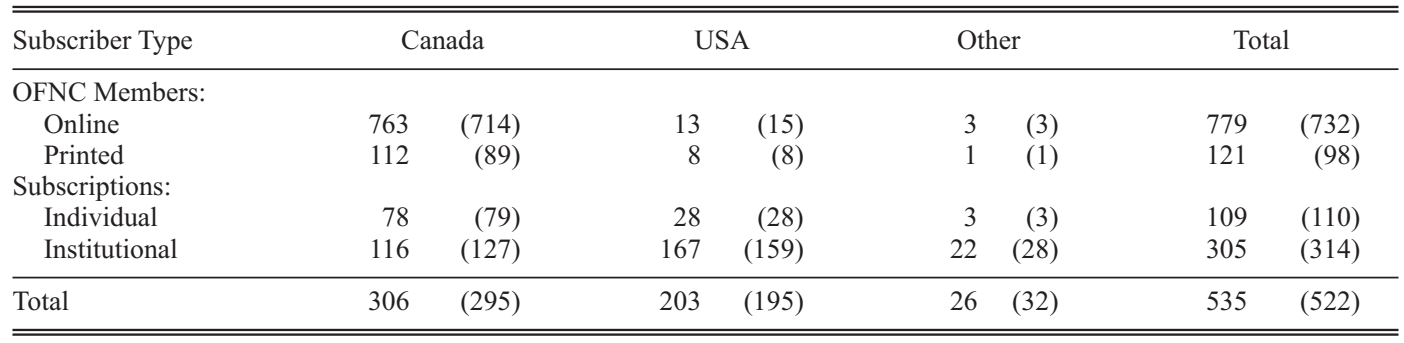


TABLE 2. Number of research and observation articles and notes published in The Canadian Field-Naturalist, Volume 128 , by major field of study.

\begin{tabular}{lccr}
\hline \hline Subject & Articles & Notes & Total \\
\hline Mammals & 5 & 7 & 12 \\
Birds & 12 & 3 & 15 \\
Amphibians and Reptiles & 5 & 0 & 5 \\
Fish & 2 & 1 & 3 \\
Plants & 1 & 2 & 3 \\
Insects & 0 & 1 & 1 \\
Other & 3 & 0 & 3 \\
\hline Total & 28 & 14 & 42 \\
\hline \hline
\end{tabular}

TABLE 3. Number of reviews and new titles published in the Book Review section of The Canadian Field-Naturalist, Volume 128, by topic.

\begin{tabular}{lcc}
\hline \hline & Reviews & New Titles \\
\hline Zoology & 28 & 49 \\
Botany & 5 & 5 \\
Environment & 4 & 0 \\
Miscellaneous & 5 & 29 \\
Children & 0 & 7 \\
\hline Total & 42 & 90 \\
\hline \hline
\end{tabular}

The following referees reviewed manuscripts published in volume 128 (number of manuscripts reviewed $>1$ in parentheses): Ken Abraham, Ontario Ministry of Natural Resources (emeritus); Peter Achuff, Parks Canada (emeritus); Gary Anweiler, Edmonton AB; Sarah Baldo, University of Windsor; March Bechard, Boise State University; Robb Bennett, Royal British Columbia Museum Research Associate; Charles Blem, Virginia Commonwealth University (emeritus); Eric Benbow, Michigan State University; James Bogart, University of Guelph (emertius); Francois Bolduc, Canadian Wildlife Service, University of Quebec Rimouski; Rudy Boonstra, University of Toronto; Ronald J. Brooks, University of Guelph (emeritus); Syd Cannings, Canadian Wildlife Service; Leslie Carraway, University of Oregon; Suzanne Carriere, Northwest Territories Wildlife Division; Kristina Cockle, Louisiana State University; Peter Cott, Wilfred Laurier University; Robert Curry, Villanova University; Chris Darimont, University of Victoria; Jean-Francois Desroches, CEGEP Sherbrooke; Tony Diamond, University of New Brunswick; Anna Drake, Simon Fraser University; Brian Eaton, Alberta Innovates; Kerry Foresman, University of Montana; Charles Francis, Canadian Wildlife Service; Tony Gaston, Environment Canada (emeritius); John Gilhen, Nova Scotia Museum of Natural History; Scott Gillingwater, Upper Thames Conservation Authority; Laurie Goodrich, Hawk Mountain Sanctuary Association; Purnima Govindarajulu, British Columbia Ministry of Environment; Lee Grapentine, Environment Canada; Patrick Gregory University of Victoria;
TABLE 4. Number of pages per section published in The Canadian Field-Naturalist, Volume 128 (2014), by issue.

\begin{tabular}{|c|c|c|c|c|c|}
\hline & \multicolumn{4}{|c|}{ Issue } & \multirow[b]{2}{*}{ Total } \\
\hline & 1 & 2 & 3 & 4 & \\
\hline Editorials & 0 & 3 & 0 & 0 & 3 \\
\hline Articles & 71 & 78 & 37 & 89 & 275 \\
\hline Notes & 12 & 18 & 16 & 0 & 46 \\
\hline Book Reviews* & 19 & 10 & 19 & 15 & 63 \\
\hline \multicolumn{6}{|c|}{ News and Comment, } \\
\hline Reports** & 1 & 3 & 13 & 4 & 21 \\
\hline Tributes & 7 & 0 & 19 & 0 & 26 \\
\hline Index & - & - & - & 8 & 8 \\
\hline Total & 110 & 112 & 104 & 116 & 442 \\
\hline
\end{tabular}

*Includes reviews and new titles listings

**Includes CFN Editor's report, Minutes of the OFNC Annual Business Meeting, and OFNC Awards report.

Peter Hall, Ottawa ON; Gary Hanes, Carleton Place ON; Stuart Houston, University of Saskatchewan (emeritus); David Howerter, Ducks Unlimited Canada; Gabriella Ibarguchi, Queens University; Samuel Iverson, Carleton University; Haley Kenyon, University of British Columbia; Erin Koen, Trent University; Don Lafontaine, Agriculture and Agri-Food Canada; Marcus Lashley, North Carolina State University; Ross Layberry, Fitzroy Harbour ON; Laurie Lee, Government of Nunavut; Jen Lento, University of New Brunswick; Jeremy Lundholm, Saint Mary's University; Carlos Ludica, Susquehanna University; Stephen MacDonald, University of New Mexico; Kris Maier, Gwich'in Renewable Resources Board; Mark Mallory, Acadia University; Donald McAlpine, New Brunswick Museum; Shannon McCauley, University of Toronto; Jim McLaughlin, Ontario Ministry of Natural Resources; Julie MoranFerron, University of Ottawa; Bob Montgomery, Queens University; Garth Mowat, Government of British Columbia; Dennis Murray, Trent University; Mark O’Donoghue, Yukon Department of Environment (2); Mike Oldham, Ontario Ministry of Natural Resources; Alexei M. Orlov, Russian Federation Research Institute of Fisheries and Oceanography; Jane Packard, Texas A\&M University; Allysia Park, Saint Mary's University; Dave Prescott, Alberta Department of Fish and Wildlife, Environment and Sustainable Resource Development; Chuck Priestley, STRIX ecological consulting; Jamie Pinzon, University of Alberta; Rob Rempel, Ontario Ministry of Natural Resources; Greg Robertson, Environment Canada; Jeffery Rowell, Toronto ON; Brett Sandercook, Kansas State University; John Sauer, United States Geological Survey; Frederick W. Schueler, Bishop Mills Natural History Centre (3); Dave Seburn, Ottawa ON; Carolyn Seburn, Environment Canada; Fred Scott, Wildlife Museum Acadia University; Jeffrey Skevington, Agriculture and Agri-Food Canada; Jill Soha, Duke University; Bridget Stuchbury, York University; Tom Sullivan, University of British Columbia; Jon Swenson, Norwegian University of Life 
Sciences; A. M. Tokranov, Russian Academy of Science; Karen Vanderwolf, Canadian Wildlife Federation; Jeroen Van Houdt, Royal Museum for Central Aftrica, Belgium; Joseph Veech, Texas State University; Richard Weir, British Columbia Ministry of Environment; Wayne Weller, Ontario Power Generation.

The journal was printed at Gilmore Printers, Ottawa. Thanks to Mike Datson of Gilmore Printers for overseeing production and printing. I am grateful to the Ottawa Field-Naturalists' Club President Fenja Brodo and the club's Council for their support of the journal. I am also grateful to all of the individual subscribers and authors who support our team as we strive to provide a highquality scientific journal on natural history. Finally, we thank our families for being patient and supportive throughout many evenings and weekends of working on the journal.

CAROLYN CALLAGHAN

Editor in Chief

TRINA RYTWINSKI

Assistant Editor 